\title{
PKM Expanding Market Share Through Training on-Line Sales for Producers of Kripik Cassava in Kotaanyar Probolinggo
}

\author{
Musthafa Syukur ${ }^{1}$, A. Redho Bastian², Abd. Malik ${ }^{3}$, \\ Issadur Rofik ${ }^{4}$, Rohikin Makhtum ${ }^{5}$, Rahmat Mashura ${ }^{6}$, Firman ${ }^{7}$ \\ Universitas Nurul Jadid, Probolinggo, Indonesia 1,2,3,4,5,6,7 \\ \{ musthafamadinnj@gmail.com ${ }^{1,2,3,4,5,6,7}$ \}
}

Keywords:

market share, online sales, kripik cassava

Katakunci: pangsa pasar penjualan online, kripik singkong
Abstract. The purpose of online sales training for producers of various chips at Kotaanyar, Probolinggois to help these businesses out of the difficulty to expand market share. This training elaborates how to do online sales and create marketing networks become more widespread due to this training. Based on observations, all the craftsmen still apply conventional marketing its range is limited. It means that the marketing strategies implemented are still out of date. Meanwhile, many competitors have implemented modern information technology. Therefore, online sales training can assist the craftsmen in extending market share, reducing the cost of logistics and also other distribution costs. Further, this training proved beneficial for management to improve profitability. In addition, this sales-driven information technology can also reduce marketing costs significantly. In short, based on the observation, post-training provided the benefits of increased sales, which contribute to the sustainability of the producers of cassava chips at Kotaanyar, Probolinggo.

Abstrak. Tujuan pelatihan penjualan online bagi produsen aneka keripik di Kotaanyar, Probolinggo adalah untuk membantu para pelaku usaha tersebut keluar dari kesulitan untuk memperluas pangsa pasar. Pelatihan ini menjelaskan bagaimana melakukan penjualan online dan membuat jaringan pemasaran menjadi lebih luas karena pelatihan ini. Berdasarkan pengamatan, semua pengrajin masih menerapkan pemasaran konvensional yang jangkauannya terbatas. Artinya, strategi pemasaran yang diterapkan masih ketinggalan zaman. Sementara itu, banyak pesaing telah menerapkan teknologi informasi modern. Oleh karena itu, pelatihan penjualan online dapat membantu para pengrajin dalam memperluas pangsa pasar, menekan biaya logistik dan juga biaya distribusi lainnya. Lebih lanjut, pelatihan ini terbukti bermanfaat bagi manajemen untuk meningkatkan profitabilitas. Selain itu, teknologi informasi berbasis penjualan ini juga dapat mengurangi biaya pemasaran secara signifikan. Singkatnya, berdasarkan pengamatan, pasca pelatihan memberikan manfaat peningkatan penjualan, yang berkontribusi pada keberlanjutan usaha di berbagai produsen keripik singkong di Kotaanyar, Probolinggo. 


\section{Introduction}

The condition of the craftsmen of various cassava chips in Kotaanyar, Probolinggo is a very good concern. It is because the development is quite slow. Back in 2010, the number was ten and now it turns out to be the same (primary data, 2016). Whichapprehensive, the turnover is running slopingly. This fact certainly cannot be tolerated because the implications are very large on the chain of other business entities, including the loss of employment opportunities for the surrounding community.

For this reason, a strategic solution is needed to make Kotaanyar, Probolinggo, one of the centers for various cassava chips producers in the Regency Probolinggo. Of course, as a business entity, it was established with various main objectives, including earning a profit, increasing sales volume, and maintaining company survival. The profit mission is considered the main goal for every actor's effort. Of course, it will be achieved when its strengths exceed its weaknesses. Therefore, every business entity must be able to exploit the opportunities and business strengths that exist and eliminate threats and weaknesses in the surrounding business and begin to take advantage of advances in information technology.

To achieve these goals, business management needs to pay attention to two things: The main factors are internal and external. External factors are the business environment covering the company's operations that often create business opportunities and threats. In contrast, internal factors are the environment that can identify the strengths and weaknesses of the weakness of the company's economic resources. The development of small and medium enterprises is the basis for improving the national economy. Most of the in Indonesia are small and medium enterprises, which absorb a lot of labor and utilize domestic resources. Among small and medium enterprises, enterprises making chips have quite interesting characteristics. With the global crisis that hit the world today and pressure from various parties, including less biased government policies, it turns out that this industry has not died. Instead makes them persist and look for gaps to expand their business. Like most small and medium enterprises, these small-scale companies do not rely too much on banks or other financial institutions (Riyanto, 2009). Majority of small businesses obtain capital from the owner. For financial management and bookkeeping as well using a very simple method. As for the marketing of crispy products, still using conventional methods with shops already scattered in several areas in Kotaanyar, Probolinggo. We need a new marketing strategy, which reach is wider with website media known as online sales. HoweverThus, the combination of conventional marketing and online sales will certainly impact market share 
expansion and business performance. As for the product of cassava chips produced and marketed is shown in Figure 1, below

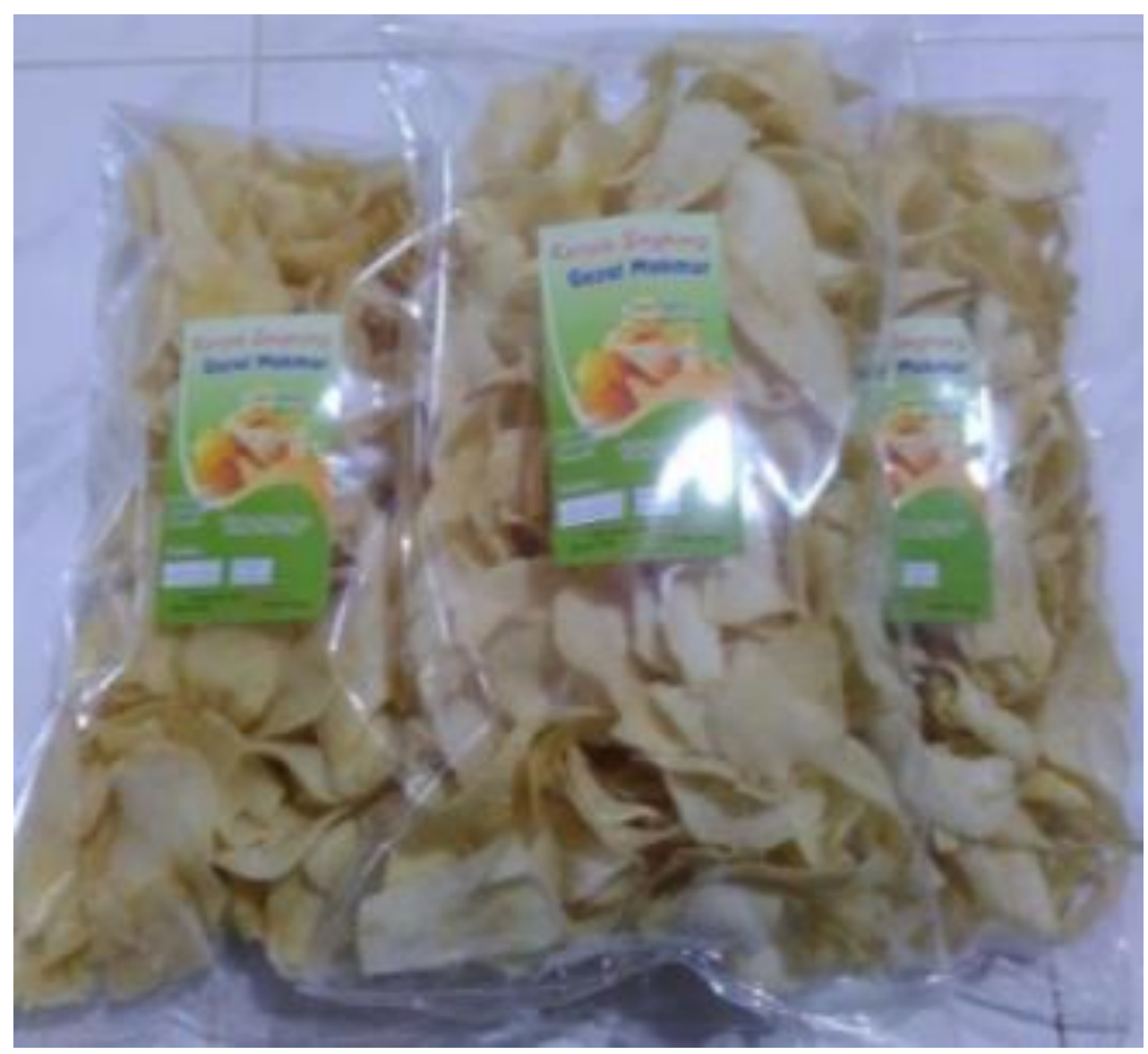

Figure 1. Cassava Chips Products

According to Sholekan (2009); Diana (2000), and Dubelaar et al. (2005), conventional trade activities are the actions of companies selling goods and services to generate income in the form of money, which in turn generates net profit from the difference in income minus market prices plus operating costs.

Electronic commerce does something similar to traditional trading but has advantages that can directly increase turnover and company profits (Ridho, 2009; Amrullah, 2011; Ajmal et al., 2012). The flexibility of electronic commerce can cut marketing costs by its ease and sophistication in conveying information about goods and services directly to consumers wherever they are. Companies that do business electronics can also cut store operating costs because they don't need to display their goods in a large store with many employees. Trade-in electronics offers producers short and long-term benefits. Trading not only opens up new markets for 
the products and services offered, reaches new customers, but it can also make it easier for producers to do business.

The production machines used are very simple and fall into the technology category appropriate as Figure 2 below. This technology was obtained by craftsmen from the Corporate program social Responsibility (CSR) from PT. PowerGen Paiton, Probolinggo. But unfortunately, The CSR program is not accompanied by training on how to build a business effectively, such as marketing strategies that take advantage of technological developments up-to-date information.

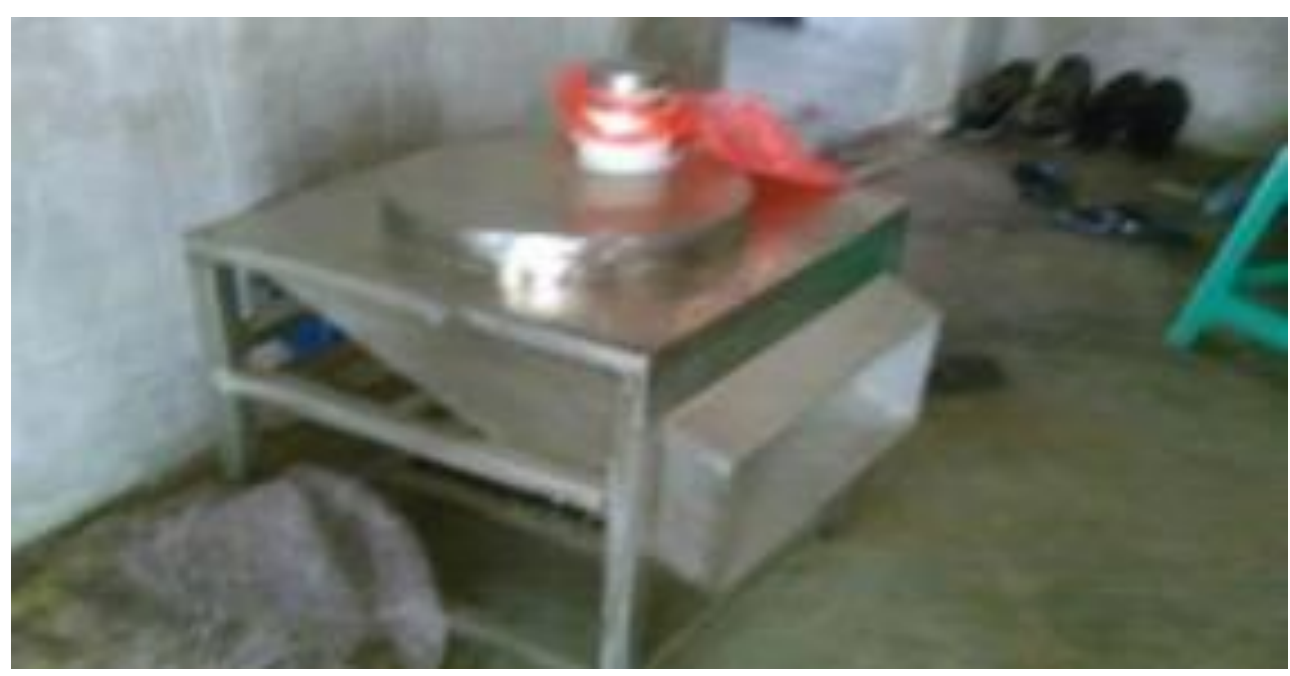

Figure 2. Production Machine

Trading by utilizing this technology is beneficial for people, customers/consumers, and the general public. In general, there are various other benefits when conducting electronic commerce. First, business actors can get closer to the consumer. By simply clicking on the links on the site, consumers can go to companies wherever they are. Second, the reach of marketing is becoming increasingly broad and not limited by geographic area wherever the company is located. Third, it is very difficult for a company to know the geographical position partners in other countries or continents on traditional trade.

After all, partners are very important for good consultation and cooperation, technical and non-technical. Electronic commerce via the internet network is not a big problem anymore. Fourth, electronic commerce will be very cut operating costs. Companies that trade electronically do not need large offices and shops, saving paper used for transactions, advertising, and recording. In addition, electronic commerce is also very efficient in terms of time used. 
Searching for product and transaction information can be done more quickly and accurately. Meanwhile, consumers can obtain information about the products they need and transact quickly and cheaply. Consumers do not need to go to the local storage companies to peddle their goods, allowing consumers to transact safely (Galih, 2009; Hartanto, 2011; Lestari, 2011). Because in certain areas, it may be very dangerous to drive and carry large amounts of cash, and consumers can make transactions from various locations, whether from home, office, internet cafe, or other places. Consumers also do not need to dress neatly as in traditional trade. Of course, online sales to various cassava chip producers in IndonesiaKotaanyar, Probolinggo will also provide many benefits. One of them will restore the title of Kotaanyar, Probolinggo, as a center for producers of various cassava chips, and at the same time, it will increase local revenue. Formulation of the problem of various craftsmenCassava chips in Kotaanyar, Probolinggo, have been carried out in a participatory manner through discussion groups, direct observation in the field, sharing information, and good experiences with business actors as well as with the Department of Industry and Trade as the leading sector small industrial development. Based on information and direct observations in the field, it was revealed that most business actors were ready to accept new technologies and innovations. It is considering that although various product innovations have been carried out, because the marketing pattern is still conventional, and the marketing reach is relatively limited, it ultimately does not contribute much to its business performance. The implication is that the number of Craftsmenthe variety of cassava chips that are still actively operating is decreasing, as is the resultfield observations made. While the location of the producer, production activities, and equipment used are as follows:

For this reason, the formulation of the problem of this activity includes (1) how the training is effective online sales to various cassava chips producers, (2) how to conduct online sales training simulations, and (3) How to apply sales online, which has succeeded in increasing the marketing reach of various chips craftsmen products in IndonesiaKotaanyar, Probolinggo. Furthermore, as the formulation of the problem in service activities this community, the specific objectives of this training activity are (1) to provide knowledge of the use of sales online effective, (2) to simulate the sale online as in the real business world and (3) providing skills utilization of online sales that are beneficial for market expansion as well as improved marketing performance. 


\section{Method}

\section{Troubleshooting Framework}

The problem-solving approach is carried out through the Active Learning and Learning method simulation Training (ALST). Active participation of training participants is carried out so that the target can be achieved in a relatively limited duration. Simulation activities are carried out to provide real knowledge and skills. For that first, starting with the model on-line sales introduction lectures to impart and enhance knowledge, the skills and abilities of business actors to take advantage of on-line sales; Second, increasing knowledge, skills, and abilities of business actors in marketing products through the website; Third, Improving the capabilities and skills of business actors in transactions with electronic media that are successful and safe (Diana, 2000; Setiawan, 2002; Aswin, 2006; Eliyani, 2010).

\section{Implementation Phases}

The training was carried out at the place of business of various chips producers for 3 (three) days. The choice of this place is done so as not to interfere with business activities and save costs. The training method used uses lectures and simulations with a system group. The training materials include (1) introduction to on-line sales, (2) doing advertising and marketing through on-line sales, (3) trading simulation through on-line sales, (4) real trading simulation, (5) safe trading transactions, (6) real evaluation and practice trade through on-line sales. In contrast, the training participants are all members of a community of cassava chip craftsmen in Kotaanyar, Probolinggo. However, considering the relatively few, the trainees are all member craftsmen community.

\section{Result and Discussion}

This training activity is a form of trading carried out electronically, which includes trading with internet facilities and trading with an electronic structured data exchange system runs smoothly and gets a response extraordinary from the training participants who come from the perpetrators of various cassava chip craftsmen in Kotaanyar, Probolinggo. It is because all participants consider it very important and provide prospects for the business they are engaged. Training activities are getting tremendous enthusiasm because later participants found out that with online sales, prospective consumers who want to buy goods or transactions via the internet only need internet access and its interface using a web browser. Making a sales portal online is not just a shopping portal, but a community gathering place to build a 
community base and build a market concept not just a place to buy and sell and as an information center. Service-oriented management, the combination of conception conventional and virtual services: responsive, dynamic, informative, and communicative. Information that is up to date, multi-directional communication dynamic. In short, training activities received a positive response and as a result, all participants have sufficient abilityadequate in conducting and implementing on-line sales. Of course, a training outcome which is the target of this program. This was revealed from the comparison of the results of the pre-test andposttest.

The post-test results after the training revealed that online sales to the community craftsmen of various chips in Kotaanyar, Probolinggo have been understood as a trading model relatively new. The electronic transaction mechanism begins with offering a product by a community of various cassava chips craftsmen on a website through a server located in Indonesia. The craftsmen understand when the consumer makes a purchase, the consumer will fill in the mail order that the seller has provided. Also, relatively skilled in conducting transactions on online sales. For example, the buyer's order is sent to the producer. After it is received and verifiedby the business actor, the buyer makes a payment that will go to the payment servers.

Interestingly, the trainees began to understand the benefits of paying via e-mail, smart cards, bank accounts, etc. However, $90 \%$ of the trainees prefer a secure means of payment if using Paypal. It's because PayPal is one of the most widely used payment instruments globally and the safest. The majority (65\%) understand that PayPal covers up weaknesses in remittancesTraditional methods such as checks or money orders are relatively time-consuming processes.

Another important skill from the training results, the craftsmen can understand the steps to make transactions through online sales. Performers of various cassava chips producers can do this by stages (1) e-customers and e-merchant meet in cyberspace through a server leased from an Internet Server Provider (ISP) by an emerchant. (2) Transactionthrough online sales accompanied by terms of use and sales terms conditions or standard clauses. Generally, e-merchant has put an agreement clause on its website, while customers select the accept button if interested. (3) Accepting e-customers via the click mechanism as the embodiment of an agreement bound to bind the e-commerce merchants. (4) When both parties reach an agreement, it is followed by the payment process, which involves two intermediary banks from each party, acquiring merchant bank and issuing customer bank. The procedure customer orders to the issuing customer bank for and on behalf of the customer to make several payments on the price of goods to the acquiring merchant bank addressed to the e-merchant. (5)After the payment process is 
complete, it is followed by the achievement fulfillment process by the merchant party in the form of delivery of goods according to the agreement regarding the delivery and specifications of goods. Post-test results reveal transaction skills with relatively good online sales, although approximately $25 \%$ of them are still needed assistance. Then, based on the results of observations for 5 (five) months posttraining, the turnover of 10 actors of various cassava chips in Kotaanyar, Probolinggo being a trainee, is shown in the following graph.

Based on the sales trend of Assorted Crispy Craftsmen from Kotaanyar, Probolinggoit was revealed that his marketing turnover increased at 5 (five) months post-training. Transaction skills by utilizing information technology provide many benefits to improve its marketing performance. Even in five months has increased from 310 balls to 778 balls. HoweverNevertheless, several obstacles are still encountered, mainly in fulfilling the right order time. That's because most of these craftsmen have limited production capacity as many small industry problems in general. Thus, capital assistance from the Department of Industry and Trade of Probolinggo Regency is necessary. Because if it is not done, it will backfire on the possibility of switching traders ordering the chips at other merchants who are competitors.

\section{Conclusion}

Based on the implementation of training activities on various producers, chips in Kotaanyar, Probolinggo, it was revealed that online sales are the urgent need for trainees who are representatives of craftsmen. It was revealed from the attitudes and responses of the trainees who played a very active role. But most importantly, the outcomes of this training implementation are: participants who can transact online sales can be realized. Then, based on post-training observations, its marketing performance has increased significantly. However, further training is needed in the future, considering thatThe development of information technology is getting faster in recent times.

\section{References}

Ajmal et al. (2012). Electronic Commerce Adoption Model for Small \& Medium Sized Enterprises. Malaysia: University of Malaya.

Amrullah, AZ. (2011). Memanfaatkan E-CommerceUntuk Pemasaran Produk Usaha Kecil Menengah. Tesis. Yogyakarta: Sekolah Tinggi Manajemen Informatika dan Komputer. 
AswinSC. (2006). Keabsahan Kontrak Dalam Transaksi Komersial Elektronik. Tesis. Semarang: Penerbit Universitas Diponegoro.

Diana A. (2000). Mengenal E-Business. Edisi Pertama. Yogyakarta: Andi offset.

Djauhari M. (2009). Optimalisasi Layanan Telepon Perdesaan. Buletin Pos dan Komunikasi. Bandung: Puslitbang Postel.

Dubelaar et al. (2005). Benefits, Impediments and Critical Success Factors in B2C EBusiness Adoption. Melbourne: Monash University.

Eliyani. (2010). Pengantar Teknologi Informasi. Jakarta: Universitas Mercu Buana.

Galih S. (2009). E-Business: Business To Consumen. Bandung:Universitas Pasundan.

Hartanto S. (2011). Pemanfaatan E-Commerce Dalam Business To Consumer Untuk Perluasan Pasar.Tesis. Surabaya: Universitas Widya Mandala.

Lestari T. (2011). Penerapan E-Commerce Pada PT.Telkom Indonesia Blog. blogs.unpad.ac.id/- tikalestari/2011/05/05/penerapan-ecommerce-pada-pttelkom-indonesia/ diakses 31 Mei 2012.

Riyanto. (2011). Membuat Sendiri Aplikasi E-Commerce dengan PHP \& MySQL Menggunakan Codelgniter \& JQuery. Yogyakarta: Andioffset.

Ridho et al. (2009). Pelatihan Aplikasi B2C untuk Sentra UKM Manik-Manik JombangJawa Timur. PKM-M, Jakarta: Universitas Indonesia.

Setiawan D. (2002). Electronic Commerce. Yogyakarta: Andi offset.

Sholekan. (2009). E-commerce Telkom PDC. Bandung: Ghalia Publishing.

Siregar AE. (1999). Perdagangan dan E-Commerce. Warta Ekonomi. 19 (11): 50-51.

Suyanto M. (2003). Strategi Periklanan pada E-Commerce Perusahaan Top Dunia. Yogyakarta: Andi offset. 